\title{
ОСОБЕННОСТИ ДЕЯТЕЛЬНОСТИ ПРОДОВОЛЬСТВЕННЫХ ОРГАНОВ ТАВРИЧЕСКОЙ ГУБЕРНИИ В НАЧАЛЬНЫЙ ПЕРИОД ГРАЖДАНСКОЙ ВОЙНЫ В РОССИИ
}

\section{ON SOME FEATURES OF THE FOOD AUTHORITIES ACTIVITY IN THE TAURIDE PROVINCE IN THE INITIAL PERIOD OF THE CIVIL WAR IN RUSSIA}

\section{A. Butovskiy}

Summary: Based on archival and memoir sources, taking into account the latest research, the article examines the history of the activities of food authorities in the Tauride province during the initial period of the Civil War in Russia. According to the author, the gradual decline of the economy on the territory of the Crimean Peninsula, typical of the first months of the Civil War in Russia, was associated with the collapse of the state, the rupture of economic ties and the beginning of the Civil War. The economic crisis that had already begun was aggravated by the mistakes made in the state food policy, which significantly contributed to the increase in economic ruin, inflation, aggravation of the food issue and unemployment on the peninsula.

Keywords: Civil War, October Revolution, Tauride province, Tauride Congress of Soviets of Workers' and Soldiers' Deputies, Provincial Food Council, People's Commissariat of Food, food issue, grain monopoly.
$\mathrm{B}$ ажнейшим моментом в истории кризисных периодов, всегда являлся продовольственный вопрос. В истории России XX века он впервые вышел на первый план еще в годы Первой Мировой войны. Уже тогда этот ключевой фактор послужил катализатором многих событий, особенно в последующий период Революций и Гражданской войны. Тем не менее, отдельных исследований, посвященных продовольственному делу и экономики в период Первой Мировой и Гражданской войны в Таврической губернии, практически нет. Правда, после работы Таврического статистика М.Е. Бененсона [1], некоторые вопросы продовольственной политики местных органов поднимались в отдельных исследованиях, но это происходило даже не контексте отдельных параграфов и глав. Исключением составляет только период с июля 1919 - по ноябрь 1920 гг. [27, с. 116-130; 28, с. 178198], который выходит за хронологические рамки нашего исследования. Тем не менее, сведения сохранившихся архивов Центральных продовольственных организаций Крыма (Таврической Губернской и Крымской Краевой Продовольственных управ), вместе с огромным объемом русского статистического материала и публикаций

\author{
Бутовский Александр Юрьевич \\ К.п.н., дочент, ФГБОУ ВО «Тульский государственный \\ педагогический университет им. Л.Н.Толстого» \\ mrvip76@mail.ru
}

Аннотация: На основании архивных и мемуарных источников, с учетом новейших исследований, в статье рассматривается история деятельности продовольственных органов в Таврической губернии в начальный период Гражданской войны в России. По мнению автора, постепенный спад экономики на территории Крымского полуострова, характерный для первых месяцев Гражданской войны в России, был связан с распадом государства, разрывом экономических связей и началом Гражданской войны. Усугубляли начавшийся экономический кризис, допущенные ошибки в государственной продовольственной политике, которые в значительной степени способствовали нарастанию хозяйственной разрухи, инфляции, обострению продовольственного вопроса и безработице на полуострове.

Ключевые слова: Гражданская война, Октябрьская революция, Таврическая губерния, Таврический съезд советов Рабочих и Солдатских депутатов, Губернская Продовольственная Управа, наркомат продовольствия, продовольственный вопрос, хлебная монополия. и отчетов в периодической печати Крыма (1914-1920 гг.), по нашему мнению, вполне позволяют провести соответствующий анализ продовольственной политики Крыма в первые месяцы революционного подъема в России.

Октябрьская революция 25 октября (7 ноября) 1917 г., многими воспринятая в качестве большевистского переворота в Петрограде, в Таврической губернии в основном также была встречена совершенно отрицательно [24, с. 234]. Губкомиссар даже старался не обращать внимание на данные события. В своей телеграмме министру внутренних дел от 24 ноября он сообщал: «Губернии порядок не нарушался. Законные власти на местах. Выборы Учредительное Собрание состоялись» [4, с. 84]. Тем не менее, Севастопольский С.Р.С.Д. и Черноморский флот, открыто поддержали новую Революцию. Командующий флотом адмирал А.В. Немитц отдал приказ о «поддержке власти советов» [16, с. 14-15; 24, с. 234; 4, с. 80]. Не вызывает сомнений, что такое прямо противоположное отношение людей к новой революции в этот сложный период развития страны, сильно повлияла сложная ситуация в стране, сложившаяся после известных февраль- 
ских событий. К осени 1917 года, она стала приобретать характер неуправляемого падения в пропасть. В Крыму спад экономики к осени 1917 года достиг катастрофических масштабов. Перестал функционировать крупнейший Керченский завод, резко сократил производство Севастопольский морской завод. Скачок цен и безработица привели к тому, что многие насущные предметы массового потребления, сделались доступными только для имущих классов. Начались погромы базаров, лавок и продовольственных баз на полуострове [12, с. 143-145].

Bсе это объясняет, почему на фоне надвигающейся катастрофы, люди в Крыму реагировали на Октябрьские события, совершенно по-разному. Симферопольский С.Р.С.Д. 27 октября вынес резолюцию, где захват власти большевиками в данный момент назван «безумной преступной авантюрой». Открывшийся в тот же день в Симферополе 6-й Таврический Губернский Съезд Крестьянских Депутатов постановил принять меры к восстановлению законной власти и своевременному созыву Учредительного собрания [24, с. 234].

Телеграмма Московского Центрального Исполнительного Комитета С.Р.С.Д., не признавшего легитимность 2-го съезда Советов в Петрограде, полученная в Крыму 27 и опубликованная 28 октября [25, с. 2-3], ясно давала понять, что в стране фактически началась Гражданская война.

Таврический губернский съезд служащих продовольственных управ, 4 ноября вынес резолюцию с протестом против захвата власти большевиками и выступил за консолидацию местных организаций для сохранения законной власти $[17$, с. 3$]$.

16 ноября в Симферополе 6-й Таврический съезд советов Рабочих и Солдатских депутатов, выслушав доклад представителей губернской продовольственной управы, о массовой незаконной скупке хлеба в северных уездах, часто вооруженными ходоками-мешочниками, принял решение о создании Комитета по охране хлебной монополии. В его состав вошли представители Исполкома Совета, Главного продовольственного комитета и делегатская комиссия фронта и потребляющих губерний. Организовывались заставы на дорогах для проверки грузов, усиливались вооруженные отряды для охраны продовольственных грузов. Принято решение при сопротивлении скупщиков принимать «крайние меры» [20, с. 3]. Кроме мешочников, острой проблемой были продовольственные комиссары СНК и Петроградского и др. С.Р.С.Д. северных губернии, снабженные не только «наказами» и «инструкциями», но вооруженной силой. На станциях постоянно совершались попытки захвата пустых вагонов для ссыпки хлеба [18, с. 4]. Продолжена отгрузка хлеба в армию. С 1 по 9 ноября руководство Главного продовольственного комитета отправило в ар- мию 75 вагонов муки и 100 вагонов зернового фуража. К середине ноября в день отправлялось до 30 вагонов. Продолжена отправка хлеба в Москву и Киев, по мере возможности в рамках старых разнарядок [7, с. 4].

1 ноября, с третьей попытки был создан Крымский Революционный Штаб (КРШ) преимущественно крымско-татарскими и украинскими организациями. Его возглавил временный председатель президиума Исполнительного комитета Крымского штаба И. Озенбашлы, а также казначей и секретарь А.А. Боданинский. Постепенно ИК пополнялся представителями других революционных организаций.

Принятый Центральной Радой III Универсал от 7 (20) ноября провозглашал создание на территории ряда южных русских губерниях Украинской Народной Республики (УНР) включал в состав незаконно провозглашенного государства всю северную Таврию, отторгая ее от Крыма и разрывая хозяйственные и экономические связи [13, с. 24-25]. За всеми этими действиями Рады, довольно отчетливо просматривалась Германия, политика которой по отношению к России уже давно была направлена через поддержку всяческой «самостийности»: украинской, грузинской и т.д. [12, с. 223].

14 ноября на заседании Таврического губернского комиссариата при участии представителей Крымского Революционного Штаба, решено реорганизовать Губернский комиссариат. Товарищем комиссаром был избран А.С. Озенбашлы, а его заместителем начальник Симферопольской уездной милиции и член Губернской Украинской рады прапорщик П.С. Близнюк [12, с. 215; 6. с. 184,186$]$.

В результате Земско-Городского собора 20-23 ноября 1917 г., вызванного в большей степени 3-м Универсалом УНР, чем Октябрьскими событиями в Петрограде был избран Совет народных представителей Таврической губернии. Председателем президиума Совета народных представителей Таврической губернии с 24 ноября 1917 г. стал Штван Иван Иванович. Таврическим губернским комиссаром Совета народных представителей (Исполнительная власть) - Бианки Павел Иванович [5, с. 3]. А.А. Стевен, продолжил руководство системой продовольственной организаций Таврической губернии [19, с. 2]. Не без его активного участия Земско-Городской собор принял резолюцию о сохранении хлебной монополии в губернии. 23 ноября Съезд также постановил: с 1 января 1918 г. начать передачу низовых организации волостных продовольственных управ - волостному земству, как шаг к ликвидации монополии $[19$, с. 2].

Начавшийся 23 ноября Губернский кооперативный съезд, также поддержал сохранение хлебной монополии, но потребовал более широкого сотрудничества 
Главного продовольственного комитета с кооперативами [14, с. 2].

25 ноября - 13 декабря в Бахчисарае открылся Курултай (Учредительный съезд) Крымско-Татарского Народа. Были приняты «Крымско-Татарские основные законы» и сформировано национальное правительство Директория, часть членов которой входила в состав Совет народных представителей (СНП) [15, с. 34-38; 21, с. $107-113 ; 22$, с. 110, 170]. Правое большинство во главе с Дж. Сейдаметом считало незаконными притязания на «высокую краевую власть», которую олицетворял Совет народных представителей [26, с. 119].

Таким образом, на фоне довольно агрессивной политики Центральной Рады в течение нескольких недель на территории Крыма возникла сложная ситуация, которую можно условно назвать «кондоминиумом» Совета Народных Представителей, Крымско-Татарской Директории и Советов рабочих, солдатских, и крестьянских депутатов разных уровней.

Вооруженными силами Совета народных представителей и Крымско-Татарской директории декларировались войска гарнизонов Крымского полуострова (кроме Севастополя и Черноморского флота) формально подчиненные Штабу Крымских войск (создан 30.11.1917 г., и официально объявивший о начале своей работы 19.12.1917 г.) [17, с. 3].

В результате кровопролитной гражданской войны со 2 по 14 января 1918г. между Севастопольским Военно-Революционным Комитетом и Войсками Крымского штаба [2, с. 5-18], последние, были преданны своими руководителями. 14 января 1918 года еще сопротивляющиеся большевикам отряды получили сообщение - приказ, подписанный председателем Курултая А.С. Айвазовым и Председателем ВРК Ж. Миллером. Из него следовало, что Курултай и ВРК подписали перемирие, распустили Крымский Штаб, войскам предписывалось прекратить сопротивление и перейти на «мирное положение» $[3$, c. 169].

Власть в Крыму перешла в руки Севастопольского Военно-Революционного комитета, который 22.01 (4.02) был переименован в Областной [24, с. 264]. Черноморским флотом теоретически управлял Центрофлот, причем обе организации в большинстве случаев признавали Петроградский СНК и его распоряжения. Юг России и соответственно Крым погрузился в кровавый хаос революционного передела, системного и бессистемного террора [12, с. 226 -227]. 28-29 января 1918г. в Севастополе проведен «чрезвычайный съезд исполкомов и военно-революционных комитетов». Руководствуясь Декретом от 24 декабря 1917 г. Ц.И.К.С.Р., С. и Кр. Депутатов в Петрограде о передаче всех продовольственных организаций в ведение продовольственных комиссий при советах большевики начали реорганизации органов контроля за продовольствием. Предлагалось перевести административный центр в Севастополь, куда, следовательно, должна была переместиться и Губернская Продовольственная Управа. Надо сказать, что против этого активно возражал ряд делегатов (всего 47), в том числе единственный представитель Поалей-Цион И. Столяр.

В дальнейшем регулирование продовольственной деятельностью на полуострове происходило при Советской Социалистической Республике Таврида, которая по прямому распоряжению В.И. Ленина и СНК была создана 9(22) марта 1918 года [9; 11]. Территория Тавриды теперь включала в себя Симферопольский, Феодосийский, Ялтинский, Евпаторийский и Перекопский уезды Республики [3, с. 229]. При этом Совет народного хозяйства решили не создавать, а функции руководства работой заводов, предприятий и снабжения их всем необходимым, возложить на наркомат продовольствия [11, с. 69]. Аппарат нового наркомата продовольствия включал 7 отделов (делопроизводств), часть из которых ведала организационной, инструкторской, контрольноревизионной работой, бухгалтерским учетом, а другая часть - непосредственно снабжением, распределением, заготовкой огромной номенклатуры товаров. Имелись здесь и собственные секретариат, юридическая часть, регистратура, заведования личным составом и хозяйственной частью. Эта структура досталась наркомату в наследство от Главного продовольственного комитета [11, с. 117-118]. Наромат возглавили А.В. Столяр, левый эсер (с 25 марта) и И.Ф. Федосеев, большевик (с 8 апреля) [10, с. 13]. Именно благодаря этим людям были сохранены структура и аппарат бывшего комитета. 1 апреля, по предложению И. Ф. Федосеева наркомат переформирован в Наркомат снабжения и Продовольствия [11, с. 116].

Основной задачей большевики, осознавая свое шаткое положение в Крыму, ставили снабжение армии и северных губерний. Всего по свидетельству Ю.П Гавена., с января по первую половину апреля, из Крыма было «выкачано твердой рукой три половиной миллиона пудов хлебопродуктов» [8, с. 49]. Это фактически 573324 тонн. Резкому сокращению торгового оборота также способствовало введение государственной монополии на хлеб, текстиль, нефть, спички, свечи, сельскохозяйственные машины и т.п. Натуральный продуктообмен (бартер), постепенно вытеснял денежные отношения. Нормативное запрещение частной торговли привело к тому, что областью торговых отношений стал сохранившийся подпольный «черный рынок», где эти отношения были деформированы и искажены. Все это способствовало нарастанию хозяйственной разрухи, инфляции, обострению продовольственного вопроса и безработице в Республике Таврида [11, с. 115]. 
Таким образом, в первые месяцы Гражданской войны в России, на территории Крымского полуострова происходил постепенный спад экономики, который был связан с распадом государства, разрывом экономических связей и началом Гражданской войны. Усугубляли начав- шийся экономический кризис, допущенные ошибки в государственной продовольственной политике, которые в значительной степени способствовали нарастанию хозяйственной разрухи, инфляции, обострению продовольственного вопроса и безработице на полуострове.

\section{ЛИТЕРАТУРА}

1. Бененсон М.Е. Экономические очерки Крыма. Симферополь: Южно-Кооперативное Издательство, 1919. 78 с.

2. Бобков А.А. К истории Вооруженных сил Крымско-татарской директории 1917- январь 1918 гг. // Белая Гвардия — Белое дело. 2002. № 11. С. 5-18.

3. Борьба за Советскую власть в Крыму: Документы и материалы в 2 т. Т. 1: (Март 1917 г. - апрель 1918 г.) / Парт. архив Крымского обкома КП Украины. Гос. архив Крымской обл. / Под ред. П.Н. Надинского Симферополь: Крымиздат, 1957. 320 с.

4. Бунегин М.Ф. Революция и гражданская война в Крыму (1917 - 1920 гг.) / Комис. по подгот. и проведению празднования 10-летия Окт. рев. при ЦИК Кр. АССР. Симферополь: Крымгосиздат, 1927. 336 с.

5. В Совете Народных Представителей // Земля и воля: Ежедневная газета. Издание Таврического Областного Комитета Партии Социалистов-Революционеров и Таврического Губернского Совета Крестьянских Депутатов. 1917 (воскресенье, 26 ноября). № 40. С. 3.

6. Вінцковський Т. Українські національні організації Таврійської губернії у політичному протистоянні жовтня-листопада 1917 р. // Краєзнавство. 2011. № 1. С. с. $181-190$.

7. Вывоз хлеба из Тавриды в армию // Земля и воля: Ежедневная газета. Издание Таврического Областного Комитета Партии Социалистов-Революционеров и Таврического Губернского Совета Крестьянских Депутатов. 1917 (воскресенье, 19 ноября). № 35. С. 4.

8. Гавен Ю.П. Первые шаги советской власти в Крыму // Революция в Крыму. Исторический сборник Истпарта Крыма. Симферополь, 1923. №2. С. $39-56$.

9. Гарчев П.І., Кононенко Л.П., Максименко М.М. Республіка Тавріда. Київ: Політвидав України, 1990. 125 с.

10. Данные о правительствах Крыма периода гражданской войны собраны и подготовлены к печати А.Г. и В.Г. Зарубиными // Известия Крымского республиканского краеведческого музея Симферополь, 1995. №11. С.12-15.

11. Дубко Ю.В. Советская Республика Тавриды: авантюра большевистского государственного строительства. Симферополь: Таврида, 1999. 208 с.

12. Зарубин А.Г., Зарубин В.Г. Без победителей. Из истории Гражданской войны в Крыму. Симферополь: АнтиквА, 2008. 728 с.

13. Кондратюк В. Державність України (1917-1920). Львів, 1992. 102 с.

14. Кооперативный съезд // Южные ведомости. Ежедневная газета Таврического земства. 1917 (вторник, 28 ноября). № 104 (269). С. 2.

15. Королев В.И. Таврическая губерния в революциях 1917 года: полит. партии и власть. Симферополь: Таврия, 1993. 85 с.

16. Королев В.И. Черноморская трагедия (Черноморский флот в политическом водовороте 1917-1918 гг.). Симферополь: Таврия, 1994. 37 с.

17. Крымская резолюция губернского съезда // Крымская почта: ежедневная газета общественно-политическая и литературная. Симферополь, 1917. № 1407 (пятница, 10 ноября). С. 3.

18. Местная жизнь // Земля и воля: Ежедневная газета. Издание Таврического Областного Комитета Партии Социалистов-Революционеров и Таврического Губернского Совета Крестьянских Депутатов. 1917 (суббота, 18 ноября). № 34. С. 4.

19. 06 организации власти // Южные ведомости. Ежедневная газета Таврического земства. 1917 (пятница, 24 ноября). № 101 (266). С 2.

20. От Таврического губернского по охране хлебной монополии // Южные ведомости. Ежедневная газета Таврического земства. 1917 (пятница, 1 декабря). № 106 (271). C. 3.

21. Первая конституция крымско-татарского народа (1917 г.) / Публикация С.М.Исхакова // Отечественная история. 1999. № 2. С. $107-113$.

22. Потемкин Е.Л. Социалисты - революционеры Таврической губернии в 1917-1918 годах / диссер. канд. истор. наук. М., 2005. 172 с.

23. Приказ о начале работы Штаба Крымских войск // ГАРК Ф. Р-998. Оп. 1. Д. 30. Л.15.

24. Революция в Крыму. Историческая библиотека Истпарта 0. К. Крыма / Истпарт, Отд. Крымского обл. ком. ВКП(б) по изуч. ист. Окт. рев. и ВКП(б). Симферополь: Крымиздат, 1927. Вып. 1/7. 288 с.

25. Телеграмма Центрального Исполнительного Комитета // Крымская почта: ежедневная газета общественно-политическая и литературная. Симферополь, 1917. № 1396 (суббота, 28 октября). С. 2 -3.

26. Хаяли Р.И. Провозглашение Крымской народной республики и принятие «Основных законов крымскотатарского курултая» (декабрь 1917 года - январь 1918 года) // Науковий вісник Ужгородського національного університету: Серія: Право / Под ред. Ю.М. Бисага. Ужгород: Видавничий дім «Гельветика», 2014. Вип. 24. Т. 1. С. $116-120$.

27. Цветков В.Ж. Аграрно-крестьянская политика Белого движения в России // Новый исторический вестник. 2007. № 1 (15). С. $116-130$.

28. Цветков В.Ж., Цветкова Е.А. Особенности регионального продовольственного рынка в Крыму и Северной Таврии в годы Гражданской войны (весна осень 1920 года) // Historia Provinciae - Журнал региональной истории. 2018. Т. 2. № 4. С. 178-198.

(с Бутовский Александр Юрьевич (mrvip76@mail.ru). 